\title{
Relationship Between Interest In Listening English Songs, Vocabulary Mastery Toward Listening Skill
}

\author{
Dimas Aditya Dwi Atmaja, Ngadiso, and Endang Setyaningsih
}

\author{
English Education Department \\ Teacher Training and Education Faculty \\ Sebelas Maret University of Surakarta
}

Email:dimasadityaatmaja@yahoo.com

\begin{abstract}
Despite of numerous researches on listening, vocabulary, and interest, there are few researches that relate the three variables in one study. This research aims at finding the correlation between interest in listening to English songs, vocabulary mastery and listening skill. The study involves 29 students of a state school in Banyudono. They were selected as the sample by using cluster random sampling. The data on students' interest in listening to English songs are collected by using questionnaire and data on students' vocabulary mastery and listening skill are collected by using test. The techniques used to analyze the data are Simple and Multiple Linear Regression and Correlation. The results indicate that: (1) interest in listening to English songs contributes to listening skill; (2) similar interaction is found between vocabulary mastery and listening skill; and (3) interest in listening to English songs and vocabulary mastery simultaneously contribute to students' listening skill.
\end{abstract}

Keywords: interest in listening to English songs, vocabulary mastery, listening skill.

\section{INTRODUCTION}

There are numerous researches in listening. One was conducted by Arevalo (2001) who found that songs are the most suitable type of authentic material to develop listening comprehension. Another research was conducted by Schoepp (2010) who is demonstrating the effectiveness of songs as a learning tool in listening class. Meanwhile, Li (2009) found that varying the degree of use of songs produces different English language achievement scores. Subjects who were exposed to the most music obtained a higher vocabulary acquisition.

However, there has been few researches that relate the three variables in one study. This study tries to look at the relationship between interest in listening to English songs, vocabulary mastery, and listening skill and to know which contributes stronger in listening skill.

Burn and Bruman (1975: 98) give a distinction between hearing and listening by saying that "hearing depends on the proper functioning of the ears, nervous system, and the brain, but listening extends hearing to reaction, identification, and thought." According to Underwood (1997: 5) listening is "the activity of paying attention to and get meaning from something we hear." In addition, Rost (1994: 2) says that listening is "a process that is triggered by our attention. In psychological terms, attention is an excitation of nerve pathways in the brain to organize incoming stimuli in an efficient way. The purpose of an attention is to help up organize and use what we see and hear." Rubin in Tuan and Loan (2010: 53) says listening as "an active process in which a 
listener selects and interprets information which comes from auditory and visual clues in order to define what is going on and what the speakers are trying to express."

Furthermore, Wipf in Wallace (1998:

244) argues that listening is "a complex problem-solving skill. Listening is more than just perception of sounds, listening also includes comprehension meaning-bearing words, phrases, clauses, sentences, and connected discourse." It means listening is a complex skill to process what the listeners heard into meaning. In order to construct meaning, listeners should start by recognizing phonetic sounds until comprehend meaning of the whole discourse which is processed in memory.

By these ideas it can be concluded that listening is an active process to select and interpret information coming from auditory and visual clues which is triggered by attention in order to define what is going on and get the meaning of what the speaker want to express correctly using a complex skill processed in memory.

Meanwhile, in finding information from spoken language in English, students often found difficulties such as: cannot find main idea of a text (most of students identify it from the title); cannot find explicit and implicit meaning (students just guess the meaning); and cannot find meaning of words (students cannot interpret the word meaning). According to Ur (1996: 111) "the problems in listening appear because students often have trouble catching sounds of the foreign language, have to understand every word, cannot understand a fast natural native speaker, need to hear things more than once, find it difficult to keep up, and get tired."

Although there are many problems and difficulties that arise in teaching listening, there are many factors that can improve listening skill of students. One of factors that can improve students' listening skill is students' interest. Hurlock (1981: 420) says that "interest provides a strong motivation to learn. Children who are interested in an activity, whether it is play or work, will put forth more effort to learn than children who are not interested or bored." It means, when students are interested in doing something, they will be motivated to learn what they are interested without being forced. So, the students will respond quickly to what they listen if they are interested or familiar with the topic in they are listening.

The examples of students' interest activity that can improve their listening skill are students' interest in playing games, watching movies, and also from listening songs. From those activities, enhancing students' interest in listening songs has many advantages in order to improve students' listening skill. By listening an English song, students can learn how to pronounce words correctly, understand the meaning of a word and how to arrange words into a good sentence. Students can also get more vocabulary from the song lyrics. Furthermore, students' interest in listening English songs also has benefits to motivate students in learning English. As Griffee (1995: 4) says "songs have personal quality that make listener react to the song." It means when students have favorite English songs to listen, students become motivated personally to find out what the song is about.

Another factor that influences students' listening skill is vocabulary mastery. Vocabulary is the basic knowledge to learn more about English. It must be mastered in order to learn English successfully. Aebersold and Field (1997: 138) say "Knowing vocabulary is important for getting meaning from a text". It is true that vocabulary mastery has contribution in learning language, especially listening, 
because knowledge of words will help students to recognize words and assign meaning to it. This idea is also supported by Coady and Huckin (1997:11) who state that "the most important thing about learning a language is accumulating new words as equivalents for concepts which they can already express in their native languages". So, Students who have great quantities of vocabulary will find less difficulty in catching words while listening because they can get meaning of words that the speaker delivers as in their native language.

Based on the rationale above, the hypotheses of the research can be formulated as follows: (1) there is a positive correlation between interest in listening to English songs and listening skill; (2) there is a positive correlation between vocabulary mastery and listening skill; and (3) there is a positive correlation between interest in listening to English songs, vocabulary mastery simultaneously, and listening skill.

\section{RESEARCH METHODS}

The research was conducted at a state school in Banyudono. The population of this research is the eleventh grade students in the academic year of 2013/2014. The sample of this research is 29 students. The research is conducted in April 2014.

The method that is used in this study is correlational study. Hallonen and Santrock (1999) define correlational study as a method to describe the relationship between two or more events or characteristics. The researcher used this method because he wanted to know the level of correlation between interest in listening to English songs, vocabulary mastery, and listening skill. There are three possible results of a correlation study: a positive correlation, a negative correlation, and no correlation.
In this research there are two kinds of variables, namely independent variable and dependent variable. The independent variables are interest in listening to English songs and vocabulary mastery, while the dependent variable is listening skill.

The researcher used questionnaire and test as the techniques to collect the data of the study. (Nawawi, 1995) states A questionnaire is a way to collect information using some written-questions that must be answered in written form. In this study the researcher used questionnaire to measure the data of interest in listening to English songs which consists of 40 items in the try-out test and 32 items in the test. The researcher used the positive and negative items.

Beside questionnaire, another techniques used to collect the data is test. "A test is activity whose main purpose is to convey (usually to the tester) how well the tester knows or can do something (Ur: 1996: 33)." The researcher used test to measure the data of vocabulary mastery and listening skill. The type of test is objective test.

The first is test on vocabulary mastery. It is used to collect the data about the students' vocabulary mastery. This test consists of 50 items in the try-out test and 38 items in the test. The listening skill consists of 50 items in the try-out test and 39 items in the test.

In analyzing the data, the researcher tested the three hypotheses of the study. Product Moment Formula is used to test the first and the second hypotheses which say that there is a positive correlation between interest in listening to English songs and listening skill, and there is a positive correlation between vocabulary mastery and listening skill. Besides, to know whether the coefficient correlation between $\mathrm{X}$ and $\mathrm{Y}$ is significant or not, the researcher uses $t$ test formula. The correlation coefficient is 
significant if the value of $t$ observation $\left(t_{0}\right)$ is higher than $t$ table $\left(t_{t}\right)$, or $t_{o}>t_{t}$.

Multiple Linear Correlation is used to test the third hypothesis which says that there is a positive correlation between interest in listening to English songs, vocabulary mastery simultaneously, and listening skill. Besides, to find out whether or not the coefficient of Ry $(1,2)$ is significant, the researcher uses $F$ test formula. The correlation coefficient is significant if the value of $\mathrm{F}$ observation $\left(\mathrm{F}_{\mathrm{o}}\right)$ is higher than $F$ table $\left(F_{t}\right)$, or $F_{o}>F_{t}$.

\section{RESEARCH FINDINGS AND DISCUSSIONS}

The data of interest in listening to English songs are collected by using questionnaire. From the questionnaire, it is obtained that the highest score is 105 and the lowest score is 68 , so the range is 37 . The mean of the average score is 89.8 , the mode is 97.25 and the median is 91.56 . The standard deviation is 9.74 .

The data of vocabulary mastery are collected by using test. It is obtained that the highest score 38 and the lowest score is 28 , so the range is 10 . The mean or the average score is 31.9. The mode is 32.4 and the median is 32 . The standard deviation is 2.72 .

The last is the data of listening skill which are collected by using test. It is obtained that the highest score 37 and the lowest score is 27 , so the range is 10 . The mean or the average score is 33.08. The mode is 32 and the median is 32.8 . The standard deviation is 2.64 .

The researcher used Pearson Product Moment Formula to test the first hypothesis. In the first hypothesis says that there is a positive correlation between interest in listening to English songs $\left(\mathrm{X}_{1}\right)$ and listening skill (Y). The correlation analysis shows that the correlation coefficient $\left(\mathrm{r}_{\mathrm{x} 1 \mathrm{y}}\right)$ between interest in listening to English songs $\left(\mathrm{X}_{1}\right)$ and listening skill (Y) is 0.488 . After being calculated on the basis of the t-value, the value of $t_{o}$ ( $t$ obtained) is 2.905. The value of $t_{t}$ ( $t$ table) at the level of significance $\alpha=$ 0.05 for $\mathrm{n}=29$ is 1.69. Because $\mathrm{t}_{\mathrm{o}}(2.905)>$ $t_{t}$ (1.69), it can be concluded that the coefficient correlation is significant. It means that $H_{o}$ is rejected. So, there is a positive correlation between interest in listening to English songs $\left(\mathrm{X}_{1}\right)$ and listening skill $(\mathrm{Y})$. The coefficient of determination between $\mathrm{X}_{1}$ and $\mathrm{Y}$ is 0.2382 . It means that $23.82 \%$ variance of listening skill is determined by the students' interest in listening to English songs and $76.18 \%$ variance of listening skill is determined by other factors.

The second hypothesis in this research says that there is a positive correlation between vocabulary mastery $\left(\mathrm{X}_{2}\right)$ and listening skill (Y). To test the hypothesis, the researcher analyzes the collect data by using Pearson Product Moment Formula. The correlation analysis shows that the correlation coefficient $\left(\mathrm{r}_{\mathrm{x} 2 \mathrm{y}}\right)$ between vocabulary mastery $\left(\mathrm{X}_{2}\right)$ and listening skill $(\mathrm{Y})$ is 0.627. After being calculated on the basis of the $t$-value, the value of $t_{o}$ ( $t$ obtained) is 4.183 . The value of $\mathrm{t}_{\mathrm{t}}$ ( $\mathrm{t}$ table) at the level of significance $\alpha=$ 0.05 for $n=29$ is 1.69 . Because $t_{0}(4.183)>t_{t}$ (1.69), it can be inferred that the coefficient correlation is significant. It means that $\mathrm{H}_{\mathrm{o}}$ is rejected. So, there is a positive correlation between vocabulary mastery $\left(\mathrm{X}_{2}\right)$ and listening skill (Y). The coefficient of determination between $\mathrm{X}_{2}$ and $\mathrm{Y}$ is 0.3932 . It means that $39.32 \%$ variance of listening skill is determined by students' vocabulary mastery and $60.68 \%$ variance of listening skill is determined by other factors.

In the third hypothesis, the researcher analyzed the collected data by using the Multiple Linear Regression Formula. This hypothesis says that there is a positive 
correlation between Interest in Listening to English Songs $\left(\mathrm{X}_{1}\right)$, Vocabulary Mastery $\left(\mathrm{X}_{2}\right)$ and Listening Skill (Y). The multiple linear regression analysis shows that the coefficients of $a_{0}, a_{1}, a_{2}$ are $11.2,0.07$, and 0.49. Therefore, the multiple linear regression equation of $\mathrm{Y}$ on $\mathrm{X}_{1}$ and $\mathrm{X}_{2}$ becomes $\hat{\mathrm{Y}}=11.2-0.07 \mathrm{X}_{1}+0.49 \mathrm{X}_{2}$. The value of $F_{o}$ is 10.67 and the distribution table $\left(\mathrm{F}_{\mathrm{t}}\right)$ with the degree of freedom (df) 2 and 26 at the level of significance $\alpha=0.05$ is 3.37. It is obvious that $F_{o}>F_{t}$; it means that the regression of $\mathrm{X}_{1}, \mathrm{X}_{2}$, and $\mathrm{Y}$ is significant.

The multiple correlation analysis shows that the correlation coefficient $\left(\mathrm{R}_{\mathrm{x} 1 \mathrm{x} 2 \mathrm{y}}\right)$ between Interest in Listening to English Songs $\left(\mathrm{X}_{1}\right)$, Vocabulary Mastery $\left(\mathrm{X}_{2}\right)$ and Listening Skill (Y) is 0.6714. After being calculated to the F-value, the value of Fo ( $F$ obtained) is 10.67. The value of $F_{t}$ at the level of significance $\alpha=0.05$ and $\mathrm{df}$ (degree of freedom) 2:26 for $\mathrm{N}=29$ is 3.37 . Because $F_{o}(10.67)$ is higher than $F_{t}(3.37)$, the coefficient correlation is significant. It means that $\mathrm{H}_{\mathrm{o}}$ is rejected. So, there is a positive correlation between Interest in Listening to English Songs $\left(\mathrm{X}_{1}\right)$, Vocabulary Mastery $\left(\mathrm{X}_{2}\right)$ simultaneously and Listening Skill (Y). $\mathrm{R}^{2}$ (coefficient determination) is 0.4508 . It means that $45.08 \%$ variance of listening skill is determined by the students' interest in listening to English songs $\left(\mathrm{X}_{1}\right)$ and vocabulary mastery $\left(\mathrm{X}_{2}\right)$ and $54.92 \%$ variance of listening skill is determined by other factors.

The result of the correlation analysis between two independent variables (interest in listening to English songs and vocabulary mastery) and one dependent variable (listening skill) is a positive and significant. The correlation between interest in listening to English songs, vocabulary mastery, and listening skill can be illustrated as follows:
Students' interest in listening to English songs and vocabulary mastery go hand in hand in improving students' listening skill. Through interest in listening English songs, students are helped to engage in listening activity. Students listening skill are improved because interest in listening to songs can be a very meaningful experience for students and stimulate their imagination so that they will be more motivated to pay attention and comprehend the content of such listening materials. Besides, through vocabulary mastery, students are helped to understand the content of spoken text easily since elements of vocabulary mastery such as pronunciation, which is useful in recognizing words, and meaning of the word, which helps in absorb idea, are important aspects in listening comprehension process. Sari (2012) in her study concludes that students who are involved into activities they are interested like listening to English songs and have sufficient vocabulary had better achievement in listening test. The listening test materials that is using popular song makes them enjoy to pay attention in language and the words in the songs were easy to understand as well by the students.

"Listening skill is listening with comprehension, attention, and appreciation (Rivers in Arevalo, 2010: 124)." Listening lesson could become boring since it requires listener to concentrate on the content and makes fast respond to what is heard. Through interest in listening to English songs, students' attention is raised because the use of songs motivates students to pay attention in language that is used in listening activities they are interested. Songs offer students different levels of English in order to be exposed to natural, lively, and rich language. In this way it is possible to raise students' enthusiasm and cultivate their listening interest. Simultaneously, students 
listening skill in comprehension is helped by their vocabulary mastery since it help students to be easier recognizing words and assign meaning to what they listen. According to research that is conducted by Meutia (2013) having interest in habitual activities like listening English songs and vocabulary mastery help students improve their listening skill because the structure of songs which has lyric, melody, rhythm, and repetition help students feel enjoy to pay attention to the language while vocabulary mastery bring beneficial to their listening skill since students can easily know the word and interpret the word in context.

From the explanation above, it is clear that the students' interests in listening to English songs and vocabulary mastery simultaneously build a good relationship and give contribution toward listening skill.

\section{CONCLUSIONS AND SUGGESTIONS}

From the study, it can be concluded that, first, there is a positive correlation between students' interest in listening to English songs and listening skill. It means that the increase of students' interest in listening to English songs will be followed by the increase of listening skill. It also means that students' interest in listening to English songs has contribution to their listening skill. Students' interest in listening to English songs likely contributes $23.82 \%$ to their listening skill while $76.18 \%$ of their listening skill is contributed by other factors.

Second, There is a positive correlation between vocabulary mastery and listening skill. It means that the increase of vocabulary mastery will be followed by the increase of listening skill. It also means that

students' vocabulary mastery has contribution to their listening skill. Students' vocabulary mastery likely contributes $39.32 \%$ to their listening skill while $60.68 \%$ of their listening skill is contributed by other factors.

Third, There is a positive correlation between students' interest in listening to English songs (X1) and vocabulary mastery (X2) simultaneously and listening skill (Y). It means that the increase of students' interest in listening to English songs and vocabulary mastery simultaneously will be followed by the increase of listening skill. Students' interest in listening to English songs and vocabulary mastery likely contribute $45.08 \%$ to their listening skill while $54.92 \%$ of their listening skill is contributed by other factors.

Considering the conclusion above, it is useful for the teachers to encourage the use of English songs that is very helpful for teaching and learning process because it can make students more interested in the material and make students learn enthusiastically, especially in listening class. It is important for the teachers to understand how to use English songs in teaching learning process by devide the activities into pre-listening song, while-listening song, and after-listening song. It is also very necessary for the teachers to increase students' vocabulary mastery since it is very beneficial especially to improve their listening skill. The presence of English songs can also be used as media to teach English vocabulary since they also improved the vocabulary gain of students in which will influence the students' listening skill.

For the students, the researcher gives suggestion that they should realize listening skill is important skill in learning English and can be supported by their interest in listening to English songs and vocabulary mastery. In other words, they should increase their interest in listening to English songs and vocabulary mastery to support their listening skill. 


\section{BIBLIOGRAPHY}

Aebersold, Jo Ann and Field, Mary Lee. 1997. From reading to reading teacher.Cambridge: cambridge university press.

Arevalo, E.A.R. 2010. The use of songs as a tool to work on listening and culture in EFL classes. Retrieved on 25 October 2013 from http://dialnet.unirioja.es/descarga/artic ulo/3673475.pdf

Burn, Paul C. and broman, Betty I. 1975. The Language Arts in Childhood Education. Chicago: Rand Mc Naly college Publishing company

Coady, james and Huckin, thomas. 1997. Second Language Vocabulary Acquasition. Cambridge: cambridge university press

Griffe, Dale T. 1992. Songs in Action. Prentice Hall

Hallonen, jane and Santrock, john W. 1999. Psychology: Context and Application. New york: mc graw hill

Hurlock, Elizabet b. 1978. Child Development. Mc Graw hill

Li, Xiaming. 2009. Effectiveness of music on vocabulary acquisition, langugae usage, and meaning for mainland Chinese ESL Learners.

Meutia, Zara Firsty. 2013. A correlational study on habit in listening to English songs, vocabulary mastery, and listening skill. Surakarta: Sebelas Maret University

Nawawi, H. 1995. Metode Penelitian Bidang Sosial. Yogyakarta: UGM press

Rost, M. 1994. Introducing Listening. London: penguin group

Sari, Jiati Endah. 2012. The correlation between students' ability in listening to the English songs and their vocabulary mastery. Retrieved on 25 July 2014 from http://jurnal.untad.ac.id/jurnal/index.p hp/ELTS/article/viewFile/1592/1062

Schoepp, Kevin. 2001. Reasons for Using Songs in the ESL/EFL Classroom. Retrieved on 23 October 2013 from http://iteslj.org/Articles/SchoeppSongs.html

Sharma, Neena. 2011. Strategies for developing listening skill. http://eltvoices.in/Volume1/Issue6/EV I16.2.pdf

Tuan, L.T and Loan B.T.K. 2010. Schemabuilding and Listening. Retieved on 22 October 2013 from http://www.cscanada.net/index.php/sll/ article/download/1424/1443

Ur, Penny. 1996. A Course in Language Teaching Practice and Theory. New yotk: cambridge university press

Underwood, Mary. 1997. Teaching Listening. New york: Longman

Wallace, M.J. 1998. Action Research for Language Teachers. Cambridge University Press. 